\title{
Phase equilibria in the quasiternary system $\mathrm{Ag}_{2} \mathrm{Se}-\mathrm{CdSe}-\mathrm{In}_{2} \mathrm{Se}_{3}$
}

\author{
I.A. IVASHCHENKO ${ }^{1 *}$, O.F. ZMIY ${ }^{1}$, I.D. OLEKSEYUK ${ }^{1}$ \\ ${ }^{1}$ Department of General and Inorganic Chemistry, Volyn National University, Lutsk, Ukraine \\ * Corresponding author. E-mail: inna.ivashchenko@mail.ru
}

Received September 16, 2008; accepted December 29, 2008; available on-line March 19, 2009

The quasiternary system $\mathrm{Ag}_{2} \mathrm{Se}-\mathrm{CdSe}-\mathrm{In}_{2} \mathrm{Se}_{3}$ was investigated by differential thermal analysis, XRD, microstructure analysis and microhardness measurements. From the results of the investigation and literature data, six vertical sections, the isothermal section at $820 \mathrm{~K}$ and the liquidus surface projection were constructed. The nature and the temperatures of the invariant processes in the $\mathrm{Ag}_{2} \mathrm{Se}-\mathrm{CdSe}-\mathrm{In}_{2} \mathrm{Se}_{3} \mathrm{system}_{\mathrm{C}}$ were determined. The existence of a quaternary compound, $\mathrm{Ag}_{0.4} \mathrm{Cd}_{0.4} \mathbf{I n}_{6.3} \mathrm{Se}_{10}$, was established; the compound melts incongruently at $1055 \mathrm{~K}$.

Phase diagram / Thermal analysis / X-ray powder diffraction / $\mathrm{Ag}_{2} \mathrm{Se}-\mathrm{CdSe}-\mathrm{In}_{2} \mathrm{Se}_{3}$

\section{Introduction}

The end of the XX century saw the wide application, along with the classic semiconductor materials, silicon and germanium, of chalcogenide compounds $\mathrm{A}_{2}^{\mathrm{I}} \mathrm{X}$, $\mathrm{B}^{\mathrm{II}} \mathrm{X}, \mathrm{C}_{2}^{\mathrm{III}} \mathrm{X}_{3}\left(\mathrm{~A}^{\mathrm{I}}-\mathrm{Cu}, \mathrm{Ag} ; \mathrm{B}^{\mathrm{II}}-\mathrm{Zn}, \mathrm{Cd}, \mathrm{Hg} ; \mathrm{C}^{\mathrm{III}}-\mathrm{Ga}\right.$, In; $X-S, S e, T e)$. It is well known that one of the directions of semiconductor materials science in developing new functional materials is the complication of the investigated systems and, consequently, of the compounds that form in these systems. Since the above-mentioned binary chalcogenides melt congruently and have narrow homogeneity regions, they may be the components of quasiternary systems $\mathrm{A}_{2}^{\mathrm{I}} \mathrm{X}-\mathrm{B}^{\mathrm{II}} \mathrm{X}-\mathrm{C}^{\mathrm{III}}{ }_{2} \mathrm{X}_{3}$. Ternary $\mathrm{A}^{\mathrm{I}} \mathrm{C}^{\mathrm{III}} \mathrm{X}_{2}$, and $\mathrm{B}^{\mathrm{II}} \mathrm{C}^{\mathrm{III}}{ }_{2} \mathrm{X}_{4}$, and quaternary $\mathrm{A}^{\mathrm{I}} \mathrm{B}^{\mathrm{II}}{ }_{2} \mathrm{C}^{\mathrm{III}} \mathrm{X}_{4}$ compounds with valuable physical properties were found in these systems. The systematic study of the systems $\quad \mathrm{Cu}_{2} \mathrm{Se}-\mathrm{HgSe}-\mathrm{In}_{2} \mathrm{Se}_{3} \quad[1], \quad \mathrm{Ag}_{2} \mathrm{Se}-\mathrm{CdSe}-$ $\mathrm{Ga}_{2} \mathrm{Se}_{3}$ [2], $\mathrm{Cu}_{2} \mathrm{Se}-\mathrm{CdSe}-\mathrm{In}_{2} \mathrm{Se}_{3}$ [3,4] revealed the formation of wide solid solutions of the binary, ternary and quaternary compounds. The layered quaternary compounds $\sim \mathrm{Cu}_{1.4} \mathrm{HgIn}_{16.6} \mathrm{Se}_{26.6}$, $\mathrm{Cu}_{0.6} \mathrm{Cd}_{0.7} \mathrm{In}_{6} \mathrm{Se}_{10}$ were reported for the first time in $[1,4]$. The $\mathrm{Ag}_{2} \mathrm{Se}-\mathrm{CdSe}-\mathrm{In}_{2} \mathrm{Se}_{3}$ system, which belongs to the $\mathrm{A}_{2}^{\mathrm{I}} \mathrm{X}-\mathrm{B}^{\mathrm{II}} \mathrm{X}-\mathrm{C}^{\mathrm{III}}{ }_{2} \mathrm{X}_{3}$ group, has not been systematically studied. Its investigation in the entire concentration range is of interest, to determine the boundaries of the solid solutions and the existence of new quaternary compounds. The construction of vertical sections of the quasiternary system $\mathrm{Ag}_{2} \mathrm{Se}-\mathrm{CdSe}-\mathrm{In}_{2} \mathrm{Se}_{3}$ and of its liquidus surface projection will allows us to determine the nature of the formation of the intermediate quaternary phases.

\section{Experimental}

The alloys were synthesized in quartz ampoules evacuated to a residual pressure of $0.1 \mathrm{~Pa}$ by gradual heating of the elementary components (purity of $\mathrm{Ag}-$ 99.99 wt.\%, In - 99.999 wt.\%, Se - 99.9997 wt.\%, $\mathrm{Cd}-99.999$ wt.\%) to a maximum temperature of 1200-1350 K, depending on the alloy composition. The homogenizing annealing was carried out at $820 \mathrm{~K}$ for $300 \mathrm{~h}$. The obtained alloys were studied by X-ray diffraction and differential thermal analysis. The DTA curves were recorded using $\mathrm{Pt} / \mathrm{Pt}-\mathrm{Rh}$ thermocouples at a set-up of a Thermodent regulated-heating furnace and a H307-1 XY recorder. Powder X-ray diffraction patterns of all samples were recorded using DRON$3 \mathrm{M}$ and DRON-4-13 automatic powder diffractometers $\left(\mathrm{CuK}_{\alpha}\right.$ radiation $)$. Microstructure analysis utilized an MMU-3 microscope; microhardness was measured using PMT-3M and Leica VMHT AUTO microhardness testers.

\section{Results and discussion}

\subsection{Bibliographic data on the quasibinary systems}

3.1.1. The quasibinary system $\mathrm{Ag}_{2} \mathrm{Se}-\mathrm{CdSe}$

The complete phase diagram of the $\mathrm{Ag}_{2} \mathrm{Se}-\mathrm{CdSe}$ system is presented in [5]. It is of the peritectic type with limited solid solubility of the components. The peritectic transformation point corresponds to the composition $62 \mathrm{~mol} . \% \mathrm{CdSe}$ and $1243 \mathrm{~K}$. At this temperature the solid solution of the high-temperature (HT) cubic modification of $\mathrm{Ag}_{2} \mathrm{Se}$ extends from 0 to $68 \mathrm{~mol} . \% \mathrm{CdSe}$. As the temperature decreases, the 
solid solubility of $\mathrm{CdSe}$ in $\mathrm{Ag}_{2} \mathrm{Se}$ narrows, and equals $10 \mathrm{~mol} \%$ at $823 \mathrm{~K}$. The thermograms of all samples feature an effect that corresponds to the phase transition of $\mathrm{Ag}_{2} \mathrm{Se}$ at $413 \mathrm{~K}$. The authors of [6] studied the solid solubility of $\mathrm{Ag}_{2} \mathrm{Se}$ in $\mathrm{CdSe}$ and determined that it equals $0.94 \mathrm{~mol} \% \quad \mathrm{Ag}_{2} \mathrm{Se}$ at $1063 \mathrm{~K}$. The paper [7] reports the solid solubility of $\mathrm{CdSe}$ in $\mathrm{Ag}_{2} \mathrm{Se}$ as $68 \mathrm{~mol} \% \mathrm{CdSe}$ at $1243 \mathrm{~K}$ and $2.5 \mathrm{~mol} \% \mathrm{CdSe}$ at $688 \mathrm{~K}$.

\subsubsection{The quasibinary system $\mathrm{Ag}_{2} \mathrm{Se}-\mathrm{In}_{2} \mathrm{Se}_{3}$}

The phase diagram of the $\mathrm{Ag}_{2} \mathrm{Se}-\mathrm{In}_{2} \mathrm{Se}_{3}$ system in its entire concentration range is presented in [8]. The existence of the compounds $\mathrm{AgInSe}_{2}$ and $\mathrm{AgIn}_{5} \mathrm{Se}_{8}$ was confirmed. The $\mathrm{In}_{2} \mathrm{Se}_{3}$-rich region features the existence of another compound, $\mathrm{AgIn}_{11} \mathrm{Se}_{17}$, which melts incongruently at $1077 \mathrm{~K}$. The liquidus line that corresponds to the primary crystallization of the $\beta$-solid solutions of the HT $\mathrm{AgIn}_{5} \mathrm{Se}_{8}$ modification touches the invariant horizontal line at the composition $50 \mathrm{~mol} \% \quad \mathrm{In}_{2} \mathrm{Se}_{3}$. The $\mathrm{AgInSe}_{2}$ compound melts congruently at $1060 \mathrm{~K}$. A eutectic interaction is observed between the solid solution of the HT-AgIn ${ }_{5} \mathrm{Se}_{8}$ and $\mathrm{AgIn}_{11} \mathrm{Se}_{17}$ compounds. The coordinates of the eutectic point are $1063 \mathrm{~K}, 86 \mathrm{~mol} \%$ $\mathrm{In}_{2} \mathrm{Se}_{3}$.

\subsubsection{The quasibinary system $\mathrm{CdSe}-\mathrm{In}_{2} \mathrm{Se}_{3}$}

The system was reinvestigated in [3]. The compounds $\mathrm{CdIn}_{2} \mathrm{Se}_{4}$ and $\mathrm{CdIn}_{6} \mathrm{Se}_{10}$ form by the peritectic reactions $\mathrm{L}+\gamma \Leftrightarrow \mathrm{CdIn}_{2} \mathrm{Se}_{4} \quad(1183 \mathrm{~K})$ and $\mathrm{L}+\mathrm{CdIn}_{2} \mathrm{Se}_{4} \Leftrightarrow \mathrm{CdIn}_{6} \mathrm{Se}_{10} \quad(1123 \mathrm{~K}), \quad$ respectively, where $\gamma$ is the solid solution of the HT CdSe modification. A eutectic interaction of $\mathrm{HT}-\mathrm{In}_{2} \mathrm{Se}_{3}$ and $\mathrm{CdIn}_{6} \mathrm{Se}_{10}$ occurs, with the eutectic point at $1115 \mathrm{~K}$, $82.5 \mathrm{~mol} . \% \mathrm{In}_{2} \mathrm{Se}_{3}$. The solid solubility of $\mathrm{In}_{2} \mathrm{Se}_{3}$ in $\mathrm{CdSe}$ reaches its maximum at the peritectic temperature $\left(1183 \mathrm{~K}, 32 \mathrm{~mol} . \% \mathrm{In}_{2} \mathrm{Se}_{3}\right)$ and decreases substantially with decreasing temperature (to $7 \mathrm{~mol} . \%$ $\mathrm{In}_{2} \mathrm{Se}_{3}$ at $\left.820 \mathrm{~K}\right)$. The solid solubility of CdSe in $\mathrm{In}_{2} \mathrm{Se}_{3}$ at $820 \mathrm{~K}$ is $\sim 2 \mathrm{~mol} . \% \mathrm{CdSe}$.

\subsubsection{The quasibinary system $\mathrm{AgInSe}_{2}-\mathrm{CdSe}$}

The system is quasibinary with limited solid solubility of the components [9]. The liquidus consists of the curves of primary crystallization of the $\alpha$-solid solutions of the HT AgInSe $\mathrm{A}_{2}$ modification and of the $\gamma$-solid solutions of the wurtzite HT CdSe modification. The $\alpha$ - and $\gamma$-solid solutions exhibit a eutectic interaction $L \Leftrightarrow \alpha+\gamma$; the coordinates of the invariant point are $10 \mathrm{~mol} \% \mathrm{CdSe}, 1025 \mathrm{~K}$. The $\gamma$-solid solution reaches $72 \mathrm{~mol} . \% \mathrm{AgInSe}_{2}$ at the eutectic temperature; it decreases with decreasing temperature and extends to $43 \mathrm{~mol} \% \mathrm{AgInSe}_{2}$ at the annealing temperature. The extent of the $\alpha$-solid solution range is $5 \mathrm{~mol} . \% \mathrm{CdSe}$ at the eutectic temperature; as the temperature decreases to $900 \mathrm{~K}$, the range widens to $17 \mathrm{~mol} \% \mathrm{CdSe}$. A eutectoid decomposition $\alpha \Leftrightarrow \alpha^{\prime}+\gamma$ occurs at $900 \mathrm{~K}$, where $\alpha^{\prime}$ is the solid solution of the low-temperature (LT) modification of $\mathrm{AgInSe}_{2}$. The solid solubility of CdSe in the LT $\mathrm{AgInSe}_{2}$ modification is maximum at the eutectoid temperature at $\sim 12 \mathrm{~mol} \% \mathrm{CdSe}$; it decreases to $4 \mathrm{~mol} \% \mathrm{CdSe}$ at the annealing temperature (820 K).

\subsubsection{The vertical section $\mathrm{AgIn}{ }_{5} \mathrm{Se}_{8}-\mathrm{CdIn}_{2} \mathrm{Se}_{4}$}

The major part of this section is quasibinary [10]. The part $0-5 \mathrm{~mol} . \% \mathrm{AgIn}_{5} \mathrm{Se}_{8}$ and $1170-1195 \mathrm{~K}$ is nonquasibinary due to the incongruent melting of the $\mathrm{CdIn}_{2} \mathrm{Se}_{4}$ compound. The section liquidus consists of three parts: the primary crystallization of the $\beta$-solid solution range of $\mathrm{HT}-\mathrm{AgIn}{ }_{5} \mathrm{Se}_{8}$, of the $\varepsilon$-solid solution range of $\mathrm{CdIn}_{2} \mathrm{Se}_{4}$, and of the $\gamma$-solid solution range of HT-CdSe. The $\beta$ - and $\varepsilon$-solid solutions exhibit a eutectic interaction, the coordinates of the invariant point being $12 \mathrm{~mol} \% \mathrm{CdIn}_{2} \mathrm{Se}_{4}, 1050 \mathrm{~K}$. At this temperature the $\beta$-solid solution extends to $10 \mathrm{~mol} . \%$ $\mathrm{CdIn}_{2} \mathrm{Se}_{4}$, and the extent of the $\varepsilon$-solid solution is 54 mol.\% $\mathrm{AgIn}_{5} \mathrm{Se}_{8}$. As the temperature decreases to $1025 \mathrm{~K}$, the range of the $\beta$-solid solution increases to $15 \mathrm{~mol} . \% \mathrm{CdIn}_{2} \mathrm{Se}_{4}$, while the boundary of the $\varepsilon$-solid solution somewhat narrows to $\sim 47 \mathrm{~mol} . \% \mathrm{AgIn}_{5} \mathrm{Se}_{8}$. A peritectoid interaction of the $\beta$ - and $\varepsilon$-solid solutions $\beta+\varepsilon \Leftrightarrow \beta^{\prime}$ takes place at $1025 \mathrm{~K}\left(\beta^{\prime}\right.$ is the solid solution of the $\mathrm{LT} \mathrm{AgIn}_{5} \mathrm{Se}_{8}$ modification). The region of the $\beta$ '-solid solution at $820 \mathrm{~K}$ is small $(\sim 3 \mathrm{~mol} \%$ $\mathrm{CdIn}_{2} \mathrm{Se}_{4}$ ), whereas the solid solubility of $\mathrm{AgIn}_{5} \mathrm{Se}_{8}$ in $\mathrm{CdIn}_{2} \mathrm{Se}_{4}$ is $13 \mathrm{~mol} \%$.

\subsubsection{The isothermal section of the $\mathrm{Ag}_{2} \mathrm{Se}-\mathrm{CdSe}-$} $\mathrm{In}_{2} \mathrm{Se}_{3}$ system at $820 \mathrm{~K}$

The isothermal section of the $\mathrm{Ag}_{2} \mathrm{Se}-\mathrm{CdSe}-\mathrm{In}_{2} \mathrm{Se}_{3}$ system at $820 \mathrm{~K}$ was reported by us in [11] (Fig. 1). Wide regions of two-phase equilibria of the solid solutions of the HT modifications of $\mathrm{Ag}_{2} \mathrm{Se}$ and CdSe, the LT modifications of $\mathrm{AgInSe}_{2}$ and $\mathrm{AgIn}_{5} \mathrm{Se}_{8}$, of $\mathrm{CdIn}_{2} \mathrm{Se}_{4}$, and of one of the polymorphous modifications of $\mathrm{In}_{2} \mathrm{Se}_{3}$, separate the $\mathrm{Ag}_{2} \mathrm{Se}-\mathrm{CdSe}-$ $\mathrm{In}_{2} \mathrm{Se}_{3}$ system into quasiternary sub-systems of various sizes. There is one quaternary compound in this system, $\sim \mathrm{Ag}_{0.4} \mathrm{Cd}_{0.4} \mathrm{In}_{6.3} \mathrm{Se}_{10}$. The composition was estimated from the results of the X-Ray phase analysis. The two-phase equilibria of the compounds $\mathrm{AgIn}_{5} \mathrm{Se}_{8}, \mathrm{AgIn}_{11} \mathrm{Se}_{17}, \mathrm{Ag}_{0.4} \mathrm{Cd}_{0.4} \mathrm{In}_{6.3} \mathrm{Se}_{10}, \mathrm{CdIn}_{6} \mathrm{Se}_{10}$, $\mathrm{In}_{2} \mathrm{Se}_{3}$, that split the investigated system in the $\mathrm{In}_{2} \mathrm{Se}_{3}-$ rich region, are given by dotted lines because the crystal structure of the quaternary phase has not been determined. The phase compositions of all synthesized alloys are shown in Fig. 2.

\subsection{The quasiternary system $\mathrm{Ag}_{2} \mathrm{Se}-\mathrm{CdSe}-\mathrm{In}_{2} \mathrm{Se}_{3}$} 3.2.1 The vertical section " $\mathrm{Ag} \mathrm{C}_{2} \mathrm{Cd}_{4} \mathrm{Se}_{5}$ " - " $\mathrm{Ag} g_{6} \mathrm{In}_{4} \mathrm{Se}_{9}$ " The section liquidus (Fig. 3 ) is represented by the curves of primary crystallization of the $\alpha$ - and $\gamma$-solid solutions of the HT modifications of $\mathrm{AgInSe}_{2}$ and $\mathrm{CdSe}$, respectively. The section crosses two planes of invariant peritectic processes, $\mathrm{L}+\gamma \Leftrightarrow \mu+\alpha(950 \mathrm{~K})$ and $\mathrm{L}+\alpha \Leftrightarrow \mu+\alpha^{\prime}(935 \mathrm{~K})$, where $\gamma$ is the solid solution of HT-CdSe, $\mu$ the solid solution of HT- $\mathrm{Ag}_{2} \mathrm{Se}, \alpha$ the 


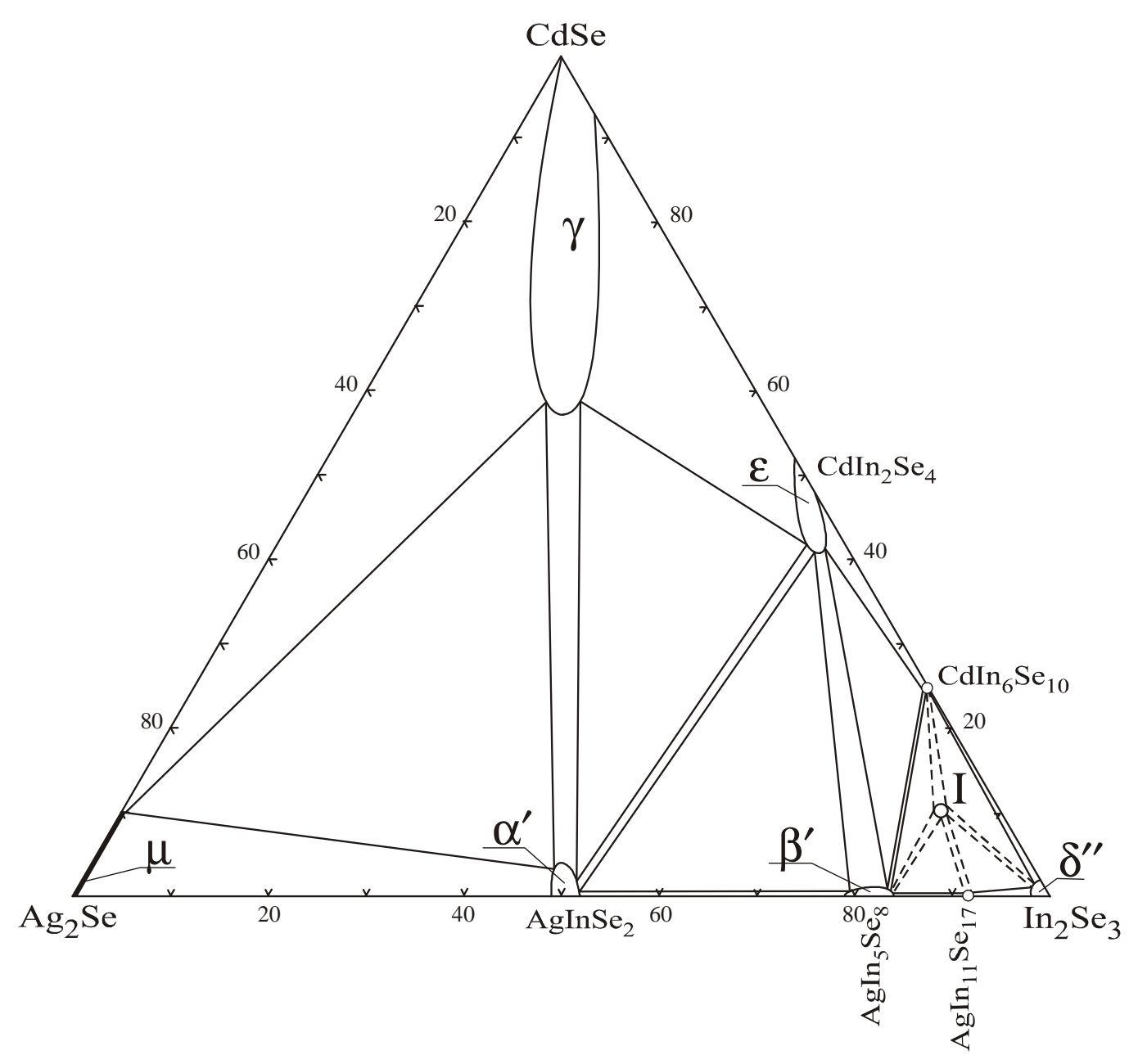

Fig. 1 Isothermal section of the quasiternary system $\mathrm{Ag}_{2} \mathrm{Se}-\mathrm{CdSe}-\mathrm{In}_{2} \mathrm{Se}_{3}$ at $820 \mathrm{~K}$ : $\mu$ - solid solution of the HT modification of $\mathrm{Ag}_{2} \mathrm{Se}, \alpha^{\prime}-$ solid solution of the LT modification of $\mathrm{AgInSe}_{2}, \gamma-$ solid solution of the HT modification of CdSe, $\varepsilon$ - solid solution of $\mathrm{CdIn}_{2} \mathrm{Se}_{4}, \beta^{\prime}-$ solid solution range of the LT modification of $\mathrm{AgIn}_{5} \mathrm{Se}_{8}, \delta^{\prime \prime}-$ solid solution of the $\mathrm{In}_{2} \mathrm{Se}_{3}$ modification that is stable at this temperature, I $\mathrm{Ag}_{0.4} \mathrm{Cd}_{0.4} \mathrm{In}_{6.3} \mathrm{Se}_{10}$.

solid solution of HT-AgInSe ${ }_{2}$, and $\alpha^{\prime}$ the solid solution of $\mathrm{LT}-\mathrm{AgInSe}_{2}$. The volumes of the secondary crystallization of the binary peritectic $\mathrm{L}+\gamma \Leftrightarrow \mu$ and the binary eutectic $\mathrm{L} \Leftrightarrow \alpha+\gamma$ converge in the plane at $950 \mathrm{~K}$. The plane at $935 \mathrm{~K}$ is the convergence of the volumes of co-existence of three-phase fields $\mathrm{L}+\mu+\alpha$ and $L+\alpha^{\prime}+\alpha$. The system solidus is represented by the curve of completion of the crystallization of the binary peritectic $\mathrm{L}+\gamma \Leftrightarrow \mu$, by the lines ab and cd that belong to the planes of the invariant peritectic processes, and by the curves bc and de of completion of the crystallization of the binary eutectics $L \Leftrightarrow \alpha+\mu$ and $\mathrm{L} \Leftrightarrow \mu+\alpha^{\prime}$. The line fg at $885 \mathrm{~K}$ belongs to the plane of the invariant eutectoid process $\alpha \Leftrightarrow \alpha^{\prime}+\mu+\gamma$; below the plane the alloys are three-phase.

\subsubsection{The vertical section $\mathrm{Ag}_{2} \mathrm{Se}_{-} \mathrm{Cd} \mathrm{In}_{2} \mathrm{Se}_{4}$}

The section liquidus is represented by the curves of primary crystallization of the $\mu$ - and $\gamma$-solid solutions of the HT $\mathrm{Ag}_{2} \mathrm{Se}$ modification and the wurtzite modification of CdSe (Fig. 4). The section crosses two quasiternary sub-systems, $\mathrm{Ag}_{2} \mathrm{Se}-\mathrm{CdSe}-\mathrm{AgInSe} \mathrm{S}_{2}$ and $\mathrm{AgInSe}_{2}-\mathrm{CdSe}-\mathrm{In}_{2} \mathrm{Se}_{3}$. Within the first sub-system the section crosses two planes of invariant peritectic processes, $\mathrm{L}+\gamma \Leftrightarrow \mu+\alpha \quad(950 \mathrm{~K})$ and $\mathrm{L}+\alpha \Leftrightarrow \mu+\alpha^{\prime}$ $(935 \mathrm{~K})$. The volumes of the secondary crystallization of the binary eutectic $\mathrm{L} \Leftrightarrow \alpha+\gamma$ and the binary peritectic $\mathrm{L}+\gamma \Leftrightarrow \mu$ converge at the first peritectic plane. The volume of co-existence of the three phases $\mathrm{L}+\mu+\alpha$ descends to the plane of the peritectic process $\mathrm{L}+\alpha \Leftrightarrow \mu+\alpha^{\prime}(935 \mathrm{~K})$. In addition to the lines bc and de that belong to the invariant planes, the solidus is represented by the curves $a b$, cd, ef of completion of the crystallization of the binary eutectics $L \Leftrightarrow \mu+\alpha^{\prime}$, $\mathrm{L} \Leftrightarrow \mu+\alpha, L \Leftrightarrow \gamma+\alpha$, by the curve of completion of the crystallization of the binary peritectic $L+\gamma \Leftrightarrow \varepsilon$, and by the curve fg that limits the region of existence of the $\gamma$-solid solution. The invariant eutectoid processes $\alpha \Leftrightarrow \alpha^{\prime}+\mu+\gamma$ and $\alpha \Leftrightarrow \alpha^{\prime}+\varepsilon+\gamma$ take place at $885 \mathrm{~K}$ in the $\mathrm{Ag}_{2} \mathrm{Se}-\mathrm{CdSe}-\mathrm{AgInSe}_{2}$ sub-system and at $890 \mathrm{~K}$ in the $\mathrm{AgInSe}{ }_{2}-\mathrm{CdSe}-\mathrm{In}_{2} \mathrm{Se}_{3}$ sub-system, respectively. The alloys are three-phase below the listed temperatures. 


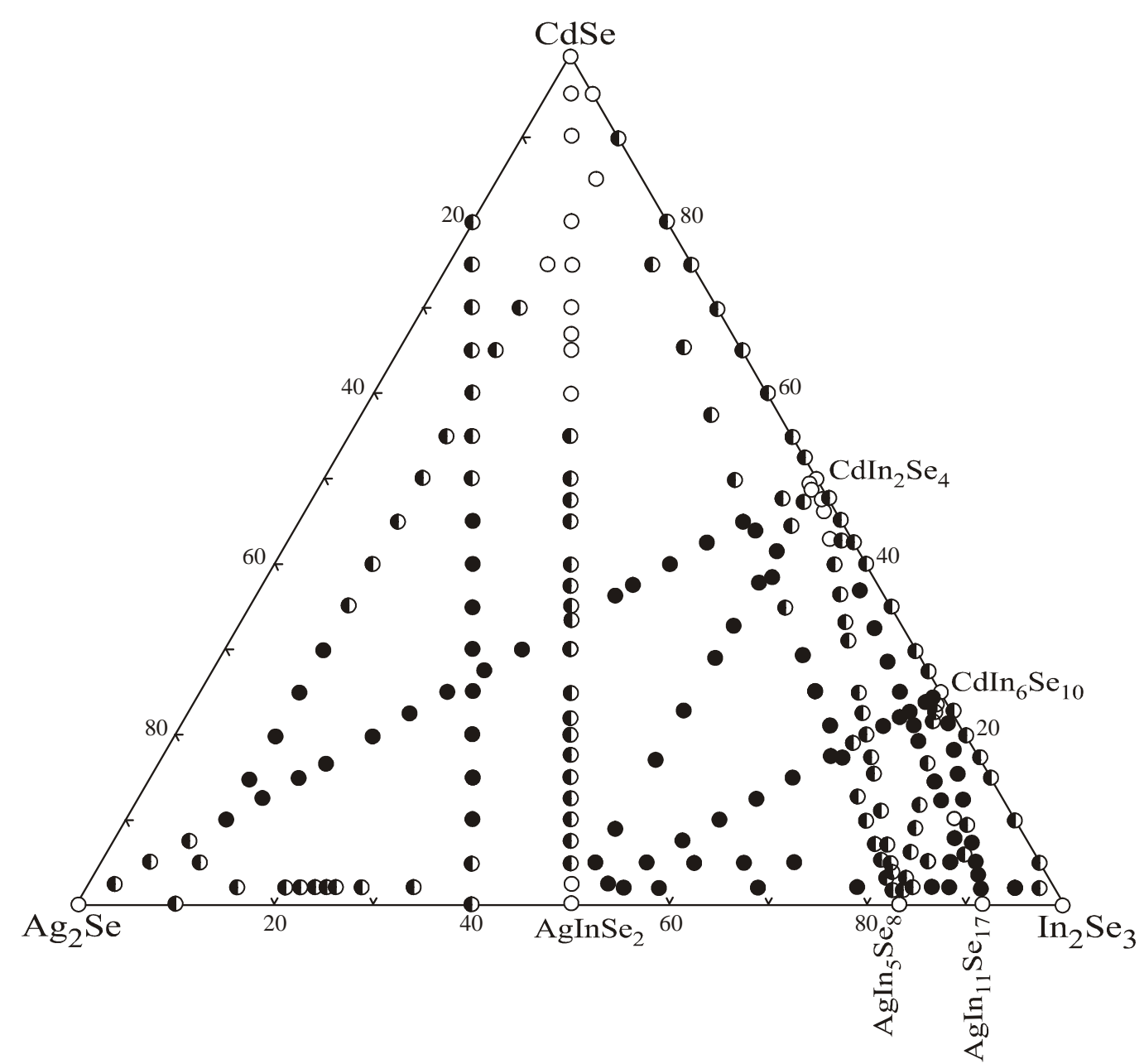

Fig. 2 Compositions of the alloys used to study the quasiternary system $\mathrm{Ag}_{2} \mathrm{Se}-\mathrm{CdSe}-\mathrm{In}_{2} \mathrm{Se}_{3}$.

\subsubsection{The vertical section $\mathrm{AgInSe} e_{2}-\mathrm{CdIn}_{2} \mathrm{Se}_{4}$}

The section crosses the fields of primary crystallization of the $\alpha$ - and $\gamma$-solid solutions of the HT modifications of $\mathrm{AgInSe}_{2}$ and CdSe (Fig. 5). It crosses the plane of the invariant peritectic process $\mathrm{L}+\gamma \Leftrightarrow \alpha+\varepsilon$ at $1010 \mathrm{~K}$. The connecting horizontal line of the plane does not coincide with the section but is shifted to $\mathrm{In}_{2} \mathrm{Se}_{3}$, therefore the alloys are three-phase $(\varepsilon+\alpha+\gamma)$ below $1010 \mathrm{~K}$. The volumes of the monovariant eutectic $(\mathrm{L} \Leftrightarrow \alpha+\gamma)$ and peritectic $(\mathrm{L}+\gamma \Leftrightarrow \varepsilon)$ processes converge at the peritectic plane. The section solidus is represented by the curves $a b$ (completion of the crystallization of the $\alpha$-solid solution), $b c$ (completion of the monovariant eutectic process $\mathrm{L} \Leftrightarrow \alpha+\gamma$ ), de (completion of the monovariant peritectic process $\mathrm{L}+\gamma \Leftrightarrow \varepsilon$ ), ef (completion of the crystallization of the $\varepsilon$-solid solution), and the line cd that lies in the plane of the invariant peritectic process at $1010 \mathrm{~K}$. In the sub-solidus region, the section crosses at $890 \mathrm{~K}$ the plane of the invariant eutectoid process $\alpha \Leftrightarrow \alpha^{\prime}+\varepsilon+\gamma$. The alloys are three-phase $\left(\alpha^{\prime}+\varepsilon+\gamma\right)$ below this temperature. This region borders on two two-phase regions, $\alpha^{\prime}+\varepsilon$ and $\alpha^{\prime}+\gamma$. The extent of the $\varepsilon$-solid solution at the annealing temperature $(820 \mathrm{~K})$ is $\sim 8 \mathrm{~mol} \% \mathrm{AgInSe}_{2}$. The microhardness changes from $2.90 \pm 0.10 \mathrm{GPa}$ for $\mathrm{CdIn}_{2} \mathrm{Se}_{4}$ to $2.74 \pm 0.10 \mathrm{GPa}$ for the alloy with composition
10 mol.\% AgInSe 2 - 90 mol.\% $\mathrm{CdIn}_{2} \mathrm{Se}_{4}$. The phase composition of all alloys of the section was ascertained by microstructure investigation.

\subsubsection{The vertical section $\mathrm{AgInSe} e_{2}-\mathrm{CdIn}_{6} \mathrm{Se}_{10}$}

The phase diagram of the $\mathrm{AgInSe}{ }_{2}-\mathrm{CdIn}_{6} \mathrm{Se}_{10}$ section is presented in Fig. 6. Its liquidus corresponds to the beginning of the primary crystallization of the $\alpha$ - and $\varepsilon$-solid solutions (of $\mathrm{HT}-\mathrm{AgInSe} \mathrm{In}_{2}$ and $\mathrm{CdIn}_{2} \mathrm{Se}_{4}$ ). Below the liquidus there are the volumes of the crystallization of two binary eutectics $L \Leftrightarrow \alpha+\varepsilon$ and $\mathrm{L} \Leftrightarrow \beta+\varepsilon$ ( $\beta$ is the solid solution of HT-AgIn ${ }_{5} \mathrm{Se}_{8}$ ), the binary peritectic $\mathrm{L}+\varepsilon \Leftrightarrow \mathrm{CdIn}_{6} \mathrm{Se}_{10}$ and a single-phase volume of $\varepsilon$-solid solution. The crystallization of the alloys ends in the invariant eutectic process $\mathrm{L} \Leftrightarrow \alpha+\varepsilon+\beta$ at $1000 \mathrm{~K}$ (part $c d$ of the solidus), the invariant peritectic process $\mathrm{L}+\varepsilon \Leftrightarrow \mathrm{CdIn}_{6} \mathrm{Se}_{10}+\beta$ at $1035 \mathrm{~K}$ (part $h k$ of the solidus), and the secondary crystallization of the binary eutectics $L \Leftrightarrow \alpha+\varepsilon$ and $\mathrm{L} \Leftrightarrow \beta+\varepsilon$ (parts $b c, d e$, and $g h$ of the solidus). The curve efg is the boundary of the region of existence of the $\varepsilon$-solid solution. The invariant eutectoid processes $\beta \Leftrightarrow \alpha+\varepsilon+\beta^{\prime}$ ( $\beta^{\prime}$ is the solid solution of $\mathrm{LT}-\mathrm{AgIn}_{5} \mathrm{Se}_{8}$ ), $\alpha \Leftrightarrow \alpha^{\prime}+\varepsilon+\beta^{\prime}$ and $\beta \Leftrightarrow \operatorname{CdIn}_{6} \operatorname{Se}_{10}+\varepsilon+\beta^{\prime}$ take place in alloys of the sections at $900 \mathrm{~K}, 890 \mathrm{~K}$ and $950 \mathrm{~K}$, respectively. 


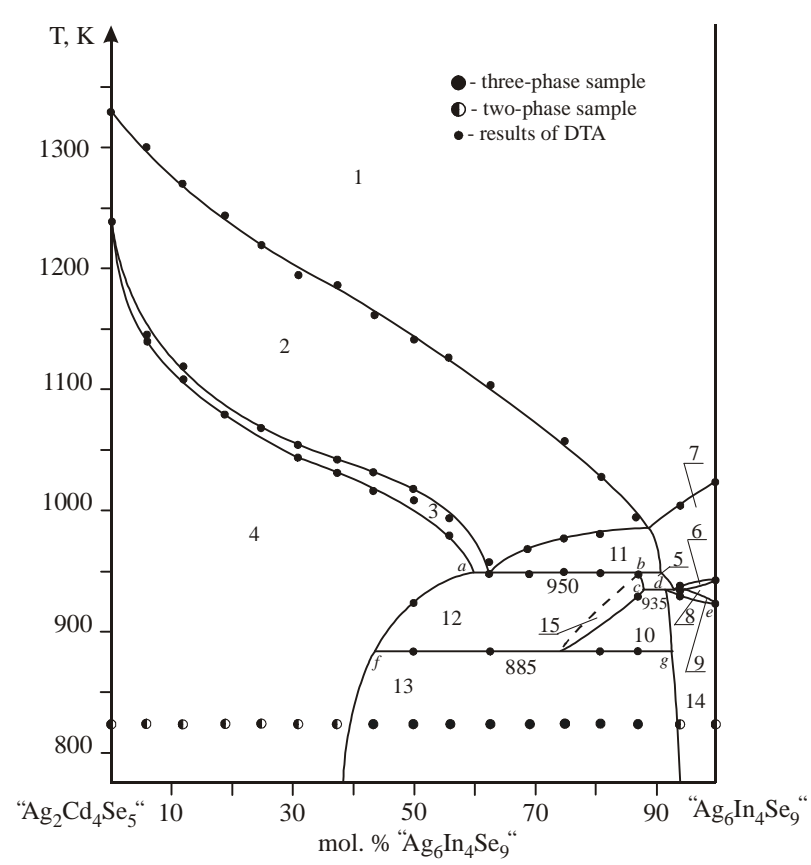

Fig. 3 Vertical section " $\mathrm{Ag}_{2} \mathrm{Cd}_{4} \mathrm{Se}_{5}$ "" $\mathrm{Ag}_{6} \mathrm{In}_{4} \mathrm{Se}_{9}$ ": (1) $\mathrm{L} ;(2) \mathrm{L}+\gamma ;(3) \mathrm{L}+\gamma+\mu$; (4) $\gamma+\mu$; (5) $\mathrm{L}+\mu+\alpha$; (6) $\mathrm{L}+\alpha+\alpha$;

(7) $\mathrm{L}+\alpha$; (8) $\mathrm{L}+\alpha^{\prime}$; (9) $\mathrm{L}+\alpha^{\prime}+\mu$;

(10) $\mu+\alpha^{\prime}+\alpha$; (11) $L+\gamma+\alpha$; (12) $\mu+\gamma+\alpha$;

(13) $\mu+\gamma+\alpha^{\prime}$; (14) $\mu+\alpha^{\prime} ;$ (15) $\mu+\alpha$.

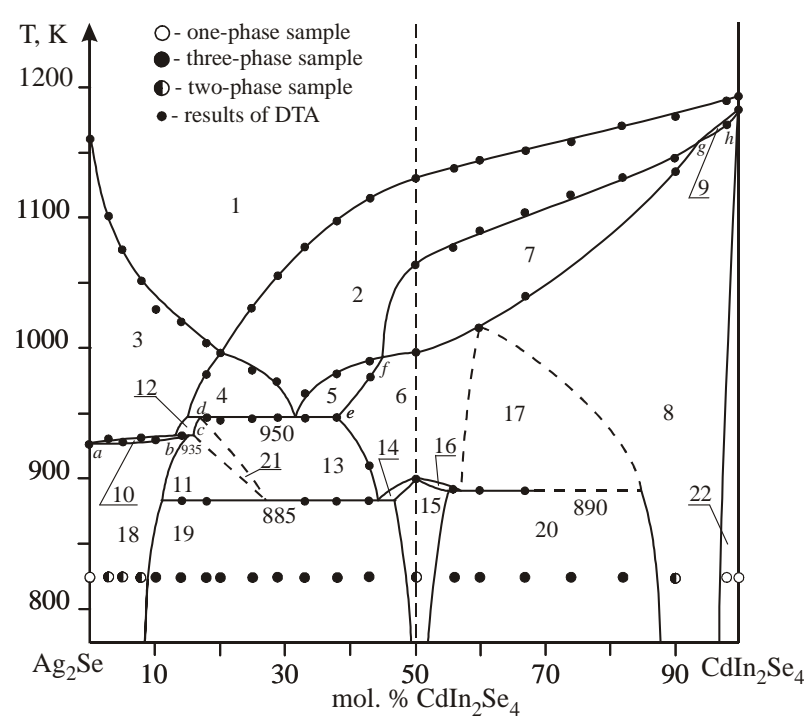

Fig. 4 Vertical section $\mathrm{Ag}_{2} \mathrm{Se}-\mathrm{CdIn}_{2} \mathrm{Se}_{4}$ :

(1) $\mathrm{L}$; (2) $\mathrm{L}+\gamma$; (3) $\mathrm{L}+\mu$; (4) $\mathrm{L}+\gamma+\mu$;

(5) $\mathrm{L}+\gamma+\alpha ;(6) \gamma+\alpha ;(7) \gamma ;(8) \gamma+\varepsilon$;

(9) $\mathrm{L}+\gamma+\varepsilon$; (10) $\mathrm{L}+\mu+\alpha^{\prime}$; (11) $\alpha+\alpha^{\prime}+\mu$;

(12) $\mathrm{L}+\mu+\alpha$; (13) $\gamma+\mu+\alpha$

$(14,16) \alpha+\alpha^{\prime}+\gamma ;(15) \alpha^{\prime}+\gamma ;(17) \alpha+\varepsilon+\gamma$;

(18) $\mu+\alpha^{\prime}$; (19) $\mu+\alpha^{\prime}+\gamma$; (20) $\varepsilon+\alpha^{\prime}+\gamma$;

(21) $\mu+\alpha ;(22) \varepsilon$.

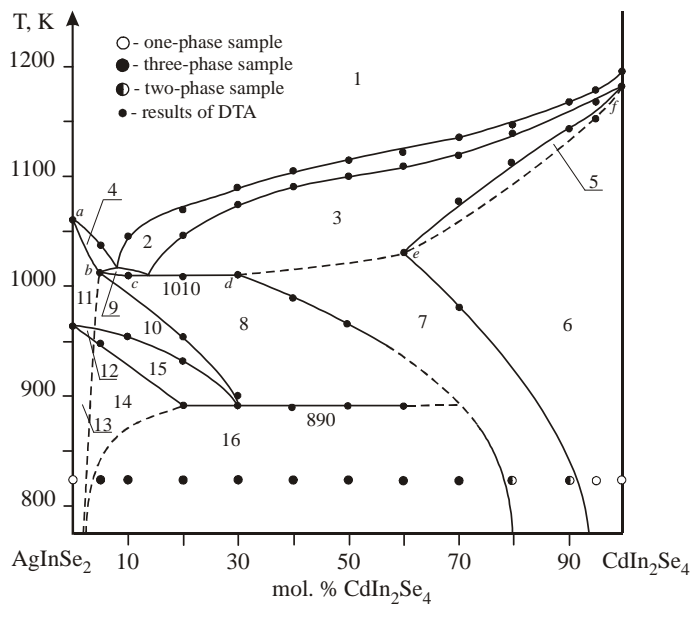

Fig. 5 Vertical section $\mathrm{AgInSe}_{2}-\mathrm{CdIn}_{2} \mathrm{Se}_{4}$ :

(1) $\mathrm{L}$; (2) $\mathrm{L}+\gamma$; (3) $\mathrm{L}+\gamma+\varepsilon$; (4) $\mathrm{L}+\alpha$;

(5) $\mathrm{L}+\varepsilon$; (6) $\varepsilon$; (7) $\varepsilon+\gamma$; (8) $\alpha+\gamma+\varepsilon$;

(9) $\mathrm{L}+\alpha+\gamma$; (10) $\alpha+\gamma$; (11) $\alpha$; (12) $\alpha+\alpha^{\prime}$;

(13) $\alpha^{\prime}$; (14) $\gamma+\alpha^{\prime}$; (15) $\gamma+\alpha^{\prime}+\alpha$;

(16) $\alpha^{\prime}+\gamma+\varepsilon$.

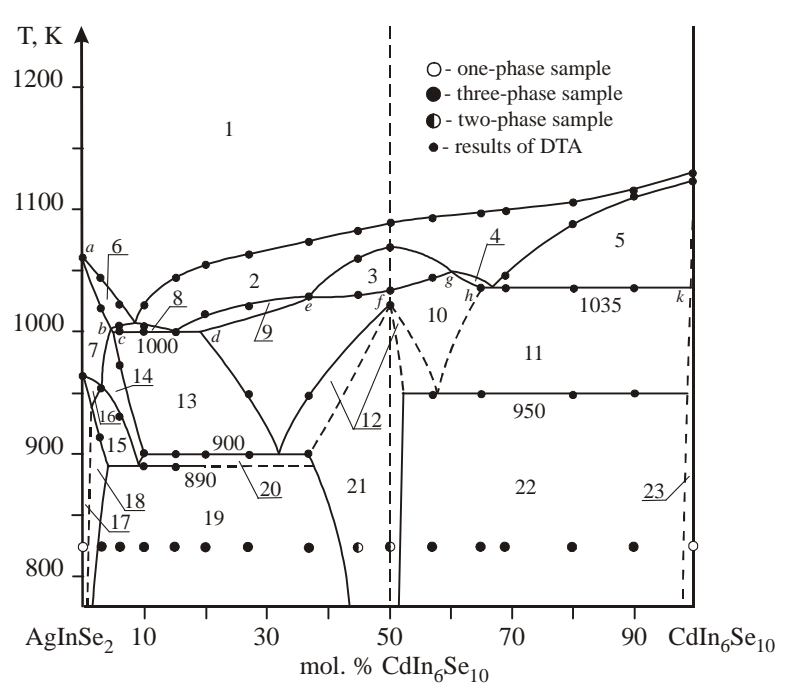

Fig. 6 Vertical section $A g I n S e=e_{2}-\mathrm{CdIn}_{6} \mathrm{Se}_{10}$ :

(1) $\mathrm{L}$; (2) $\mathrm{L}+\varepsilon$; (3) $\varepsilon$; (4) $\mathrm{L}+\varepsilon+\beta$;

(5) $\mathrm{L}+\varepsilon+\mathrm{CdIn}_{6} \mathrm{Se}_{10}$; (6) $\mathrm{L}+\alpha$; (7) $\alpha$;

(8) $\mathrm{L}+\alpha+\varepsilon ;(9) \mathrm{L}+\varepsilon+\beta$; (10) $\varepsilon+\beta$;

(11) $\varepsilon+\beta+\operatorname{CdIn}_{6} \operatorname{Se}_{10} ;$ (12) $\varepsilon+\beta+\beta^{\prime}$;

(13) $\alpha+\varepsilon+\beta$; (14) $\alpha+\varepsilon$; (15) $\alpha+\alpha^{\prime}+\varepsilon$;

(16) $\alpha+\alpha^{\prime} ;$; (17) $\alpha^{\prime} ;(18) \alpha^{\prime}+\varepsilon$;

(19) $\alpha^{\prime}+\varepsilon+\beta^{\prime} ;(20) \alpha+\varepsilon+\beta^{\prime}$;

(21) $\varepsilon+\beta^{\prime} ;$ (22) $\beta^{\prime}+\varepsilon+\operatorname{CdIn}_{6} \operatorname{Se}_{10}$;

(23) $\varepsilon+\mathrm{CdIn}_{6} \mathrm{Se}_{10}$.

3.2.5. The vertical section $\mathrm{AgIn}{ }_{5} \mathrm{Se}_{8}-\mathrm{CdIn}_{6} \mathrm{Se}_{10}$

This vertical section (Fig. 7) crosses the fields of primary crystallization of the $\beta$ - and $\varepsilon$-solid solutions (of $\mathrm{HT}-\mathrm{AgIn}_{5} \mathrm{Se}_{8}$ and $\mathrm{CdIn}_{2} \mathrm{Se}_{4}$ ). The secondary crystallization of the binary eutectic $L \Leftrightarrow \beta+\varepsilon$ and the binary peritectic $\mathrm{L}+\varepsilon \Leftrightarrow \mathrm{CdIn}{ }_{6} \mathrm{Se}_{10}$ take place below. The crystallization of the majority of the alloys ends at 
$1035 \mathrm{~K}$ in the peritectic process $\mathrm{L}+\varepsilon \Leftrightarrow \mathrm{CdIn}_{6} \mathrm{Se}_{10}+\beta$. As this section coincides with the connecting line, below $1035 \mathrm{~K}$ the alloys are two-phase $-\mathrm{CdIn}_{6} \mathrm{Se}_{10}$ and $\beta$. The eutectoid process $\beta \Leftrightarrow \operatorname{CdIn}_{6} \operatorname{Se}_{10}+\beta^{\prime}$ takes place in these samples at $985 \mathrm{~K}$; the extent of the $\beta^{\prime}$-solid solution at the eutectoid temperature is $10 \mathrm{~mol} . \% \mathrm{CdIn}_{6} \mathrm{Se}_{10}$. The solid solubility diminishes with decreasing temperature, and equals $\sim 3$ mol.\% $\mathrm{CdIn}_{6} \mathrm{Se}_{10}$ at $820 \mathrm{~K}$. The unit cell parameters vary within the $\beta$ '-solid solution from $a=0.57934(2) \mathrm{nm}$, $c=1.1622(1) \mathrm{nm}$ for $\operatorname{AgIn}_{5} \mathrm{Se}_{8}$, to $a=0.58004(2) \mathrm{nm}$, $c=1.1629(1) \mathrm{nm}$ for the two-phase alloy of composition 95 mol.\% $\mathrm{AgIn}_{5} \mathrm{Se}_{8}-5 \mathrm{~mol} . \% \mathrm{CdIn}_{6} \mathrm{Se}_{10}$. The microhardness decreases from $3.20 \pm 0.10 \mathrm{GPa}$ for $\mathrm{AgIn}_{5} \mathrm{Se}_{8}$ to $2.85 \pm 0.10 \mathrm{GPa}$ for the two-phase alloys.

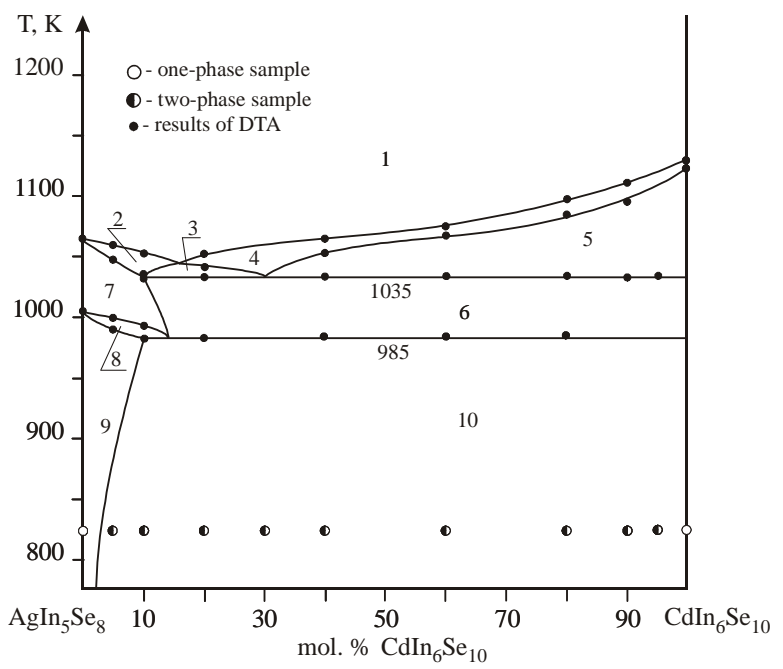

Fig. 7 Vertical section $\mathrm{AgIn}{ }_{5} \mathrm{Se}_{8}-\mathrm{CdIn}_{6} \mathrm{Se}_{10}$ :

(1) $\mathrm{L}$; (2) $\mathrm{L}+\beta$; (3) $\mathrm{L}+\beta+\varepsilon$; (4) $\mathrm{L}+\varepsilon$;

(5) $\mathrm{L}+\varepsilon+\mathrm{CdIn}_{6} \mathrm{Se}_{10} ;(6) \beta+\mathrm{CdIn}_{6} \mathrm{Se}_{10}$;

(7) $\beta$; (8) $\beta+\beta^{\prime}$; (9) $\beta^{\prime}$; (10) $\beta^{\prime}+\mathrm{CdIn}_{6} \mathrm{Se}_{10}$;

(11) $\varepsilon+\mathrm{CdIn}_{6} \mathrm{Se}_{10}$.

\subsubsection{The vertical section $\mathrm{Ag} \operatorname{In}_{11} \mathrm{Se}_{17}-\mathrm{Cd} \operatorname{In}_{6} \mathrm{Se}_{10}$}

The section liquidus is represented by the curves of primary crystallization of the $\delta$-solid solution of $\mathrm{HT}-\mathrm{In}_{2} \mathrm{Se}_{3}$, of the $\mathrm{CdIn}_{6} \mathrm{Se}_{10}$ compound and of the $\varepsilon$-solid solution of $\mathrm{CdIn}_{2} \mathrm{Se}_{4}$ (Fig. 8). Below the liquidus one finds, in addition to the fields of primary crystallization, the fields of secondary crystallization of the binary peritectic $\mathrm{L}+\delta \Leftrightarrow \mathrm{AgIn}_{11} \mathrm{Se}_{17}$, and the eutectics $\mathrm{L} \Leftrightarrow \mathrm{CdIn}_{6} \mathrm{Se}_{10}+\delta$ and $\mathrm{L} \Leftrightarrow \mathrm{Ag}_{0.4} \mathrm{Cd}_{0.4} \mathrm{In}_{6.3} \mathrm{Se}_{10}+\delta$. The section crosses at $1045 \mathrm{~K}$ the plane of the invariant peritectic process $\mathrm{L}+\mathrm{CdIn} \mathrm{Ie}_{10} \Leftrightarrow \delta+\mathrm{Ag}_{0.4} \mathrm{Cd}_{0.4} \mathrm{In}_{6.3} \mathrm{Se}_{10}$. The alloys from part bc of the section end the crystallization in this process, therefore they are three-phase $\left(\mathrm{CdIn}_{6} \mathrm{Se}_{10}+\delta+\mathrm{Ag}_{0.4} \mathrm{Cd}_{0.4} \mathrm{In}_{6.3} \mathrm{Se}_{10}\right)$ below $1045 \mathrm{~K}$. The alloys of part $\mathrm{ab}$ end their crystallization in the invariant peritectic process $\mathrm{L}+\delta \Leftrightarrow \mathrm{Ag}_{0.4} \mathrm{Cd}_{0.4} \mathrm{In}_{6.3} \mathrm{Se}_{10}+\mathrm{AgIn}_{11} \mathrm{Se}_{17}$ that takes place at $1030 \mathrm{~K}$. Below the peritectic plane, the alloys are three-phase $\left(\delta+\mathrm{Ag}_{0.4} \mathrm{Cd}_{0.4} \mathrm{In}_{6.3} \mathrm{Se}_{10}+\mathrm{AgIn}{ }_{11} \mathrm{Se}_{17}\right)$. These three-phase regions are separated by a two-phase equilibrium $\left(\delta+\mathrm{Ag}_{0.4} \mathrm{Cd}_{0.4} \mathrm{In}_{6.3} \mathrm{Se}_{10}\right)$. Its existence is caused by the point $\mathrm{b}$ lying on a connecting line, therefore the invariant process $\mathrm{L}+\mathrm{Cd} \operatorname{In}_{6} \mathrm{Se}_{10} \Leftrightarrow \delta+\mathrm{Ag}_{0.4} \mathrm{Cd}_{0.4} \mathrm{In}_{6.3} \mathrm{Se}_{10}$ in the alloy of this composition ends with the consumption of both the liquid and the crystals of the $\mathrm{CdIn}_{6} \mathrm{Se}_{10}$ compound. The investigated section crosses at $960 \mathrm{~K}$ and $895 \mathrm{~K}$ the planes of the invariant eutectoid processes $\delta \Leftrightarrow \delta^{\prime}+\mathrm{CdIn}_{6} \mathrm{Se}_{10}+\mathrm{Ag}_{0.4} \mathrm{Cd}_{0.4} \mathrm{In}_{6.3} \mathrm{Se}_{10} \quad$ and $\delta^{\prime} \Leftrightarrow \delta^{\prime \prime}+\mathrm{CdIn}_{6} \mathrm{Se}_{10}+\mathrm{Ag}_{0.4} \mathrm{Cd}_{0.4} \mathrm{In}_{6.3} \mathrm{Se}_{10}, \quad$ respectively $\left(\delta^{\prime}-\right.$ and $\delta^{\prime \prime}$ are the solid solutions of polymorphous modifications of $\left.\operatorname{In}_{2} \mathrm{Se}_{3}\right)$. The threephase samples that contain crystals of $\mathrm{Ag}_{0.4} \mathrm{Cd}_{0.4} \operatorname{In}_{6.3} \mathrm{Se}_{10}, \delta$-solid solution and $\mathrm{AgIn}_{11} \mathrm{Se}_{17}$ undergo at $965 \mathrm{~K}$ and $890 \mathrm{~K}$ the eutectoid processes $\delta \Leftrightarrow \delta^{\prime}+\operatorname{AgIn}_{11} \mathrm{Se}_{17}+\mathrm{Ag}_{0.4} \mathrm{Cd}_{0.4} \mathrm{In}_{6.3} \mathrm{Se}_{10}$ and $\delta^{\prime} \Leftrightarrow \delta^{\prime \prime}+\mathrm{AgIn}_{11} \mathrm{Se}_{17}+\mathrm{Ag}_{0.4} \mathrm{Cd}_{0.4} \mathrm{In}_{6.3} \mathrm{Se}_{10}$, respectively.

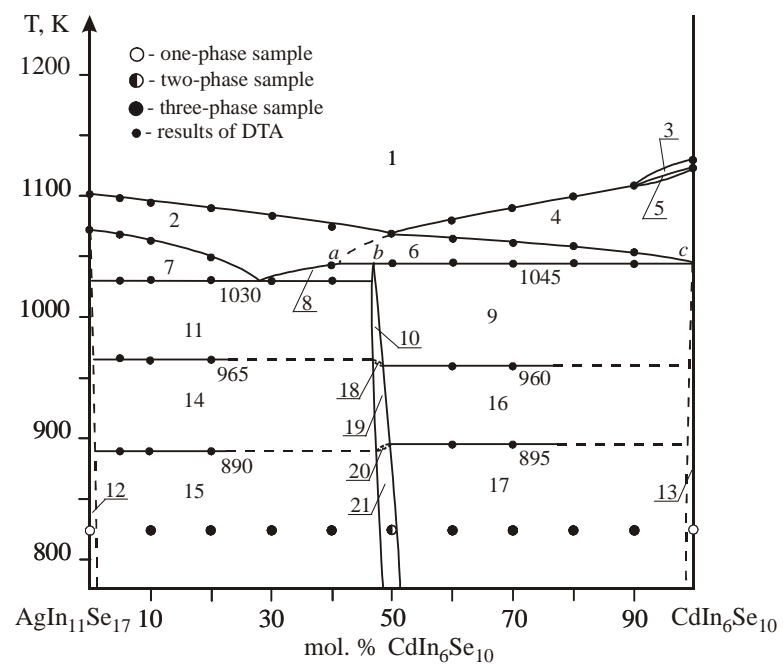

Fig. 8 Vertical section $\mathrm{AgIn}{ }_{11} \mathrm{Se}_{17}-\mathrm{CdIn}_{6} \mathrm{Se}_{10}$ :

(1) $\mathrm{L}$; (2) $\mathrm{L}+\delta$; (3) $\mathrm{L}+\varepsilon$; (4) $\mathrm{L}+\mathrm{CdIn}_{6} \mathrm{Se}_{10}$;

(5) $\mathrm{L}+\varepsilon+\mathrm{CdIn}_{6} \mathrm{Se}_{10} ;(6) \mathrm{L}+\delta+\mathrm{CdIn}_{6} \mathrm{Se}_{10}$;

(7) $\mathrm{L}+\delta+\operatorname{AgIn}_{11} \mathrm{Se}_{17}$;

(8) $\mathrm{L}+\delta+\mathrm{Ag}_{0.4} \mathrm{Cd}_{0.4} \mathrm{In}_{6.3} \mathrm{Se}_{10}$;

(9) $\mathrm{Ag}_{0.4} \mathrm{Cd}_{0.4} \mathrm{In}_{6.3} \mathrm{Se}_{10}+\mathrm{CdIn}_{6} \mathrm{Se}_{10}+\delta$;

(10) $\mathrm{Ag}_{0.4} \mathrm{Cd}_{0.4} \mathrm{In}_{6.3} \mathrm{Se}_{10}+\delta$;

(11) $\mathrm{Ag}_{0.4} \mathrm{Cd}_{0.4} \mathrm{In}_{6.3} \mathrm{Se}_{10}+\delta+\mathrm{AgIn}_{11} \mathrm{Se}_{17}$;

(12) $\mathrm{Ag}_{0.4} \mathrm{Cd}_{0.4} \mathrm{In}_{6.3} \mathrm{Se}_{10}+\mathrm{AgIn}_{11} \mathrm{Se}_{17}$;

(13) $\mathrm{Ag}_{0.4} \mathrm{Cd}_{0.4} \mathrm{In}_{6.3} \mathrm{Se}_{10}+\mathrm{CdIn}_{6} \mathrm{Se}_{10}$;

(14) $\mathrm{Ag}_{0.4} \mathrm{Cd}_{0.4} \mathrm{In}_{6.3} \mathrm{Se}_{10}+\delta^{\prime}+\mathrm{AgIn}_{11} \mathrm{Se}_{17}$;

(15) $\mathrm{Ag}_{0.4} \mathrm{Cd}_{0.4} \mathrm{In}_{6.3} \mathrm{Se}_{10}+\delta^{\prime \prime}+\mathrm{AgIn}_{11} \mathrm{Se}_{17}$;

(16) $\mathrm{Ag}_{0.4} \mathrm{Cd}_{0.4} \mathrm{In}_{6.3} \mathrm{Se}_{10}+\delta^{\prime}+\mathrm{CdIn}_{6} \mathrm{Se}_{10}$;

(17) $\mathrm{Ag}_{0.4} \mathrm{Cd}_{0.4} \mathrm{In}_{6.3} \mathrm{Se}_{10}+\delta^{\prime \prime}+\mathrm{CdIn}_{6} \mathrm{Se}_{10}$;

(18) $\mathrm{Ag}_{0.4} \mathrm{Cd}_{0.4} \mathrm{In}_{6.3} \mathrm{Se}_{10}+\delta+\delta$;

(19) $\mathrm{Ag}_{0.4} \mathrm{Cd}_{0.4} \mathrm{In}_{6.3} \mathrm{Se}_{10}+\delta^{\prime}$;

(20) $\mathrm{Ag}_{0.4} \mathrm{Cd}_{0.4} \mathrm{In}_{6.3} \mathrm{Se}_{10}+\delta^{\prime \prime}+\delta^{\prime}$;

(21) $\mathrm{Ag}_{0.4} \mathrm{Cd}_{0.4} \mathrm{In}_{6.3} \mathrm{Se}_{10}+\delta^{\prime \prime}$.

3.2.7. Projection of the liquidus surface of the quasiternary system $\mathrm{Ag}_{2} \mathrm{Se}_{-} \mathrm{In}_{2} \mathrm{Se}_{3}-\mathrm{CdSe}$

Based on the results of the present investigation and literature data, we constructed the liquidus surface projection of the quasiternary system $\mathrm{Ag}_{2} \mathrm{Se}-\mathrm{CdSe}-$ 


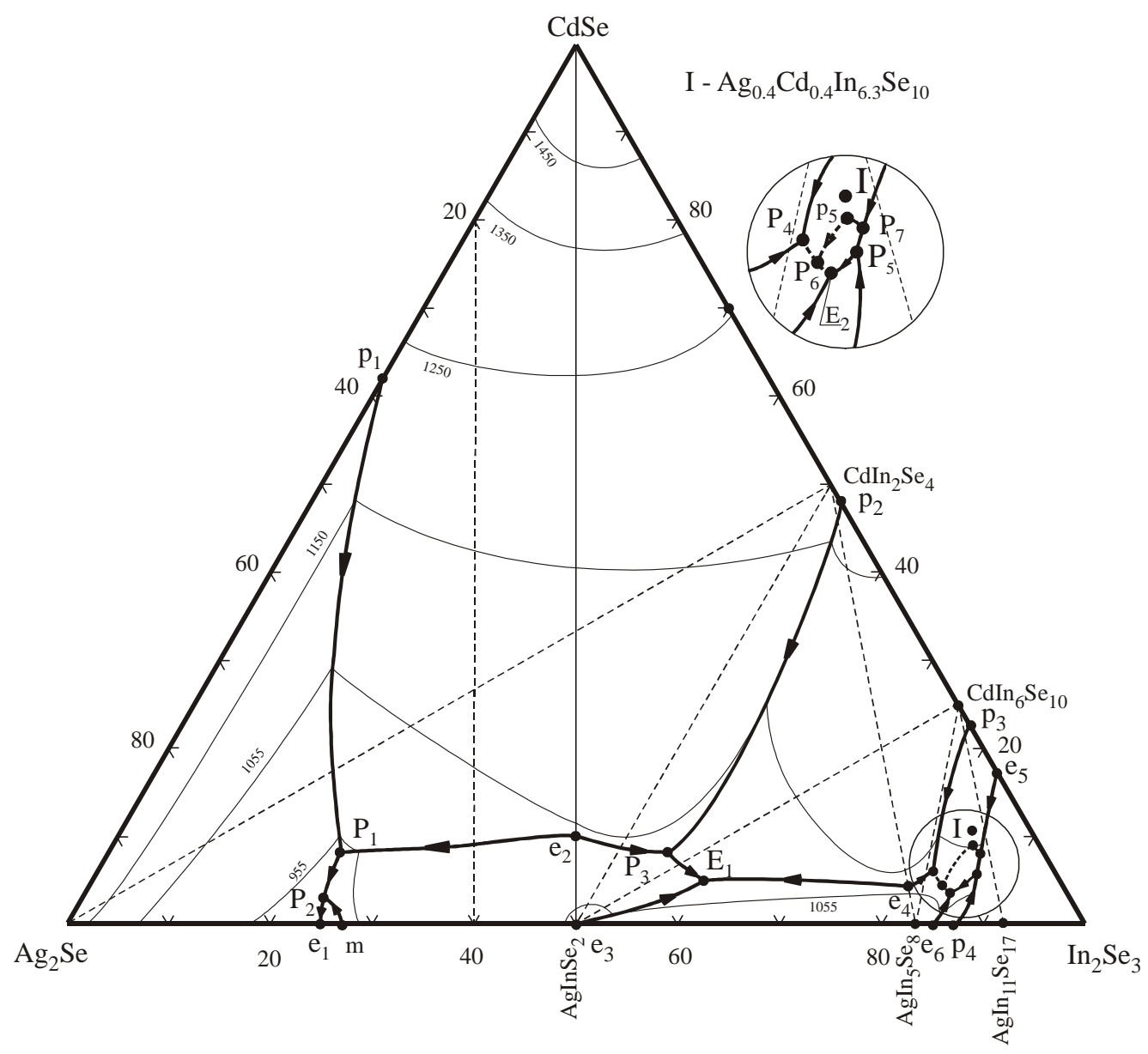

Fig. 9 Projection of the liquidus surface of the quasiternary system $\mathrm{Ag}_{2} \mathrm{Se}-\mathrm{CdSe}-\mathrm{In}_{2} \mathrm{Se}_{3}$.

$\mathrm{In}_{2} \mathrm{Se}_{3}$ onto the concentration triangle (Fig. 9). It consists of ten fields of primary crystallization of phases, of which three belong to the crystallization of the solid solutions of the system components $(\mu$-solid solution of HT- $\mathrm{Ag}_{2} \mathrm{Se}, \gamma$-solid solution of HT-CdSe and $\delta$-solid solution of $\mathrm{HT}-\mathrm{In}_{2} \mathrm{Se}_{3}$ ). Six fields belong to the crystallization of the ternary phases $\mathrm{AgInSe}_{2}$ ( $\alpha$ - and $\alpha$-solid solutions of the HT and LT modifications), $\mathrm{CdIn}_{2} \mathrm{Se}_{4}$ ( $\varepsilon$-solid solution), $\mathrm{CdIn}_{6} \mathrm{Se}_{10}$, $\mathrm{AgIn}_{5} \mathrm{Se}_{8}$ ( $\beta$-solid solution of the HT modification), $\mathrm{AgIn}_{11} \mathrm{Se}_{17}$, and one field belongs to the crystallization of the quaternary phase $\mathrm{Ag}_{0.4} \mathrm{Cd}_{0.4} \mathrm{In}_{6.3} \mathrm{Se}_{10}$. The fields of primary crystallization are separated by 20 monovariant lines and 21 invariant points, of which 12 correspond to binary invariant processes and 9 to ternary processes. The coordinates of the invariant points, the character and temperature of the invariant processes are listed in Table 1 .

In the $\mathrm{Ag}_{2} \mathrm{Se}-\mathrm{CdSe}-\mathrm{AgInSe} \mathrm{C}_{2}$ sub-system, two ternary invariant peritectic processes take place, each of which corresponds to a plane. The peritectic reaction $\mathrm{L}_{\mathrm{P} 1}+\gamma \Leftrightarrow \mu+\alpha(950 \mathrm{~K})$ takes place in the plane $\mathrm{P}_{1}-\gamma-\mu-\alpha$. The line $\mathrm{Ag}_{2} \mathrm{Se}(\mu)-\operatorname{AgInSe}_{2}(\alpha)$ splits this plane into two triangles with different nature of crystallization. The amount of liquid in the $\mu-\gamma-\alpha$ triangle is insufficient for the completion of the peritectic process, therefore the crystals of all three phases are present in the alloys below the peritectic plane. The excess of liquid in the $\mu-\mathrm{P}_{1}-\alpha$ triangle leads to full consumption of the crystals of $\gamma$-solid solution, and the crystallization of the alloys ends in another peritectic process, $\mathrm{L}_{\mathrm{P} 2}+\alpha \Leftrightarrow \mu+\alpha^{\prime} \quad$ (935 K). The temperature and composition of the invariant point $\mathrm{P}_{2}$ were refined by an additional investigation of alloys with a $\mathrm{CdSe}$ concentration of $2 \mathrm{~mol} \%$. The character of the crystallization in the peritectic quadrangle $P_{2}-\mu-\alpha-\alpha^{\prime}$ is analogous: the alloys of the $\alpha-\mu-\alpha^{\prime}$ triangle crystallize as a combination of three phases, while the alloys of the $P_{2}-\mu-\alpha^{\prime}$ triangle end the crystallization in the monovariant eutectic process $\mathrm{L} \Leftrightarrow \mu+\alpha^{\prime}$ and are two-phase $\left(\mu, \alpha^{\prime}\right)$ below the solidus surface.

Seven ternary invariant processes take place in the $\mathrm{AgInSe}_{2}-\mathrm{CdSe}-\mathrm{In}_{2} \mathrm{Se}_{3}$ sub-system, with a corresponding plane at a certain temperature. For instance, the peritectic process $\mathrm{L}_{\mathrm{P} 3}+\gamma \Leftrightarrow \alpha+\varepsilon$ occurs in the $\mathrm{P}_{3}-\alpha-\gamma-\varepsilon$ plane $(1010 \mathrm{~K})$. The line $\alpha-\varepsilon$ splits this plane into two triangles with different crystallization of the alloys. The peritectic process in the part $\gamma-\alpha-\varepsilon$ ends with an excess of crystals of $\gamma$-solid solution, therefore the alloys end their crystallization as threephase $(\gamma+\alpha+\varepsilon)$. The samples having their composition 
Table 1 Character, temperatures of invariant reactions and coordinates of invariant points of the quasiternary system $\mathrm{Ag}_{2} \mathrm{Se}-\mathrm{CdSe}-\mathrm{In}_{2} \mathrm{Se}_{3}$.

\begin{tabular}{|c|c|c|c|c|c|}
\hline \multirow{2}{*}{$\begin{array}{l}\text { Invariant } \\
\text { point }\end{array}$} & \multirow[t]{2}{*}{ Reaction } & \multirow[t]{2}{*}{$\mathrm{T}, \mathrm{K}$} & \multicolumn{3}{|c|}{ Composition, mol.\% } \\
\hline & & & $\mathrm{Ag}_{2} \mathrm{Se}$ & $\mathrm{CdSe}$ & $\mathrm{In}_{2} \mathrm{Se}_{3}$ \\
\hline $\mathrm{e}_{1}$ & $\mathrm{~L} \Leftrightarrow \mu^{\mathrm{a}}+\alpha^{\prime}$ & 927 & 75 & - & 25 \\
\hline$e_{2}$ & $\mathrm{~L} \Leftrightarrow \alpha+\gamma$ & 1025 & 45 & 10 & 45 \\
\hline$e_{3}$ & $\mathrm{~L} \Leftrightarrow \alpha+\beta$ & 1060 & 50 & - & 50 \\
\hline $\mathrm{e}_{4}$ & $\mathrm{~L} \Leftrightarrow \varepsilon+\beta$ & 1050 & 15.5 & 4 & 80.5 \\
\hline$e_{5}$ & $\mathrm{~L} \Leftrightarrow \mathrm{CdIn}_{6} \mathrm{Se}_{10}+\delta$ & 1115 & - & 17.5 & 82.5 \\
\hline $\mathrm{e}_{6}$ & $\mathrm{~L} \Leftrightarrow \beta+\operatorname{AgIn}_{11} \operatorname{Se}_{17}$ & 1063 & 15 & - & 85 \\
\hline $\mathrm{E}_{1}$ & $\mathrm{~L} \Leftrightarrow \alpha+\varepsilon+\beta$ & 1000 & 35 & 5 & 60 \\
\hline $\mathrm{E}_{2}$ & $\mathrm{~L} \Leftrightarrow \mathrm{Ag}_{0.4} \mathrm{Cd}_{0.4} \operatorname{In}_{6.3} \mathrm{Se}_{10}+\beta+\operatorname{AgIn}{ }_{11} \operatorname{Se}_{17}$ & 1005 & 11.5 & 3.5 & 85 \\
\hline $\mathrm{p}_{1}$ & $\mathrm{~L}+\gamma \Leftrightarrow \mu$ & 1240 & 38 & 62 & - \\
\hline $\mathrm{p}_{2}$ & $\mathrm{~L}+\gamma \Leftrightarrow \varepsilon$ & 1183 & - & 48 & 52 \\
\hline $\mathrm{p}_{3}$ & $\mathrm{~L}+\varepsilon \Leftrightarrow \mathrm{CdIn}_{6} \mathrm{Se}_{10}$ & 1123 & - & 22.5 & 77.5 \\
\hline $\mathrm{p}_{4}$ & $\mathrm{~L}+\delta \Leftrightarrow \mathrm{AgIn}_{11} \mathrm{Se}_{17}$ & 1077 & 13 & - & 87 \\
\hline $\mathrm{p}_{5}$ & $\mathrm{~L}+\mathrm{CdIn}{ }_{6} \mathrm{Se}_{10} \Leftrightarrow \mathrm{Ag}_{0.4} \mathrm{Cd}_{0.4} \operatorname{In}_{6.3} \mathrm{Se}_{10}$ & 1055 & 9.5 & 7 & 83.5 \\
\hline $\mathrm{P}_{1}$ & $\mathrm{~L}+\gamma \Leftrightarrow \mu+\alpha$ & 950 & 69 & 8 & 23 \\
\hline $\mathrm{P}_{2}$ & $\mathrm{~L}+\alpha \Leftrightarrow \mu+\alpha^{\prime}$ & 935 & 73 & 3 & 24 \\
\hline $\mathrm{P}_{3}$ & $\mathrm{~L}+\gamma \Leftrightarrow \varepsilon+\alpha$ & 1010 & 37 & 8 & 55 \\
\hline $\mathrm{P}_{4}$ & $\mathrm{~L}+\varepsilon \Leftrightarrow \mathrm{CdIn}_{6} \mathrm{Se}_{10}+\beta$ & 1035 & 12 & 6 & 82 \\
\hline $\mathrm{P}_{5}$ & $\mathrm{~L}+\delta \Leftrightarrow \operatorname{AgIn} \operatorname{In}_{11} \mathrm{Se}_{17}+\mathrm{Ag}_{0.4} \mathrm{Cd}_{0.4} \operatorname{In}_{6.3} \mathrm{Se}_{10}$ & 1030 & 8 & 5.5 & 86.5 \\
\hline $\mathrm{P}_{6}$ & $\mathrm{~L}+\mathrm{CdIn}{ }_{6} \mathrm{Se}_{10} \Leftrightarrow \mathrm{Ag}_{0.4} \mathrm{Cd}_{0.4} \operatorname{In}_{6.3} \mathrm{Se}_{10}+\beta$ & 1020 & 11 & 6 & 83 \\
\hline $\mathrm{P}_{7}$ & $\mathrm{~L}+\mathrm{CdIn}{ }_{6} \mathrm{Se}_{10} \Leftrightarrow \mathrm{Ag}_{0.4} \mathrm{Cd}_{0.4} \mathrm{In}_{6.3} \mathrm{Se}_{10}+\delta$ & 1045 & 9.5 & 4.5 & 86 \\
\hline $\mathrm{m}$ & $\alpha \Leftrightarrow L+\alpha^{\prime}$ & 942 & 73 & - & 27 \\
\hline
\end{tabular}

${ }^{\mathrm{a}} \mu$ - solid solution range of HT modification of $\mathrm{Ag}_{2} \mathrm{Se}, \alpha, \alpha^{\prime}-$ solid solution range of HT and LT modifications of $\mathrm{AgInSe}_{2}, \gamma-$ solid solution range of HT modification of CdSe, $\varepsilon-$ solid solution range of $\mathrm{CdIn}_{2} \mathrm{Se}_{4}, \beta, \beta^{\prime}-$ solid solution range of HT and LT modifications of $\mathrm{AgIn}_{5} \mathrm{Se}_{8}, \delta$ - solid solution range of HT modification of $\operatorname{In}_{2} \mathrm{Se}_{3}$.

inside the $\mathrm{P}_{3}-\alpha-\varepsilon$ triangle of the peritectic quadrangle end the crystallization in the invariant eutectic process $\mathrm{L}_{\mathrm{E} 1} \Leftrightarrow \alpha+\varepsilon+\beta$ at $1000 \mathrm{~K}$. The peritectic process $\mathrm{L}_{\mathrm{P} 4}+\varepsilon \Leftrightarrow \beta+\mathrm{CdIn}_{6} \mathrm{Se}_{10}$ takes place in the $\mathrm{P}_{4}-\varepsilon-\beta-\mathrm{CdIn}_{6} \mathrm{Se}_{10}$ plane $(1035 \mathrm{~K})$. The alloys falling onto the $\beta-\mathrm{CdIn}{ }_{6} \mathrm{Se}_{10}$ line of the $\mathrm{AgIn}_{5} \mathrm{Se}_{8}-\mathrm{CdIn}_{6} \mathrm{Se}_{10}$ section are two-phase below the peritectic plane, since the invariant process ends with the simultaneous consumption of both the liquid and the crystals of the $\varepsilon$-solid solution. The alloys of the $\varepsilon-\beta-C d \operatorname{In}_{6} \mathrm{Se}_{10}$ triangle crystallize as three-phase ones, while the excess of liquid in the part $\mathrm{P}_{4}-\beta-\mathrm{CdIn}_{6} \mathrm{Se}_{10}$ of the peritectic plane leads to a further monovariant eutectic process, $\mathrm{L}_{\mathrm{P} 4-\mathrm{P} 6} \Leftrightarrow \beta+\mathrm{CdIn}_{6} \mathrm{Se}_{10}$. The $\quad \mathrm{P}_{7}-\mathrm{Ag}_{0.4} \mathrm{Cd}_{0.4} \mathrm{In}_{6.3} \mathrm{Se}_{10}-\mathrm{CdIn}_{6} \mathrm{Se}_{10}-\delta$ plane features the peritectic interaction $\mathrm{L}_{\mathrm{P} 7}+\mathrm{CdIn}_{6} \mathrm{Se}_{10} \Leftrightarrow \mathrm{Ag}_{0.4} \mathrm{Cd}_{0.4} \mathrm{In}_{6.3} \mathrm{Se}_{10}+\delta \quad(1045 \mathrm{~K})$. The alloys are two-phase below the line connecting the $\mathrm{Ag}_{0.4} \mathrm{Cd}_{0.4} \mathrm{In}_{6.3} \mathrm{Se}_{10}$ compound and the $\delta$-solid solution. The crystallization of the alloys in the triangle $\mathrm{Ag}_{0.4} \mathrm{Cd}_{0.4} \mathrm{In}_{6.3} \mathrm{Se}_{10}-\mathrm{CdIn}_{6} \mathrm{Se}_{10}-\delta$ ends with the consumption of the liquid, while the alloys of the $\mathrm{P}_{7}-\mathrm{Ag}_{0.4} \mathrm{Cd}_{0.4} \mathrm{In}_{6.3} \mathrm{Se}_{10}-\delta$ triangle end the crystallization in the invariant peritectic process $\mathrm{L}_{\mathrm{P} 5}+\delta \Leftrightarrow \mathrm{Ag}_{0.4} \mathrm{Cd}_{0.4} \mathrm{In}_{6.3} \mathrm{Se}_{10}+\mathrm{AgIn}_{11} \mathrm{Se}_{17}(1030 \mathrm{~K})$. The alloys are two-phase below the connecting line of the corresponding peritectic plane between $\mathrm{Ag}_{0.4} \mathrm{Cd}_{0.4} \mathrm{In}_{6.3} \mathrm{Se}_{10}$ and $\mathrm{AgIn}{ }_{11} \mathrm{Se}_{17}$. The crystallization of the samples of the $\mathrm{Ag}_{0.4} \mathrm{Cd}_{0.4} \mathrm{In}_{6.3} \mathrm{Se}_{10}-\delta-\mathrm{AgIn}_{11} \mathrm{Se}_{17}$ triangle ends with the consumption of the liquid, while the alloys of the $\mathrm{P}_{5}-\mathrm{Ag}_{0.4} \mathrm{Cd}_{0.4} \mathrm{In}_{6.3} \mathrm{Se}_{10}-\mathrm{AgIn}_{11} \mathrm{Se}_{17}$ triangle end the crystallization in the invariant eutectic process $\quad \mathrm{L}_{\mathrm{E} 2} \Leftrightarrow \mathrm{Ag}_{0.4} \mathrm{Cd}_{0.4} \mathrm{In}_{6.3} \mathrm{Se}_{10}+\beta+\mathrm{AgIn} \mathrm{In}_{11} \mathrm{Se}_{17}$ at $1005 \mathrm{~K}$. This process ends the crystallization of all alloys of the $\mathrm{Ag}_{0.4} \mathrm{Cd}_{0.4} \mathrm{In}_{6.3} \mathrm{Se}_{10}-\mathrm{AgIn}_{11} \mathrm{Se}_{17}-\beta$ triangle. The temperature of the invariant eutectic point was ascertained by the investigation of additional synthesized alloys with CdSe concentrations of 2 and 5 mol.\% CdSe. As the crystal structure of the quaternary compound $\mathrm{Ag}_{0.4} \mathrm{Cd}_{0.4} \mathrm{In}_{6.3} \mathrm{Se}_{10}$ is not definitively established, and the composition may be adjusted, the coordinates of the invariant point $\mathrm{p} 5$ and the position of the horizontal line of the process $\mathrm{L}_{\mathrm{p} 5}+\mathrm{CdIn}_{6} \mathrm{Se}_{10} \Leftrightarrow \mathrm{Ag}_{0.4} \mathrm{Cd}_{0.4} \mathrm{In}_{6.3} \mathrm{Se}_{10} \quad(1055 \mathrm{~K})$, where this compound forms, are not definitive. For the same reason, the extent of the peritectic plane $\mathrm{P}_{7}-\mathrm{Ag}_{0.4} \mathrm{Cd}_{0.4} \mathrm{In}_{6.3} \mathrm{Se}_{10}-\mathrm{CdIn}_{6} \mathrm{Se}_{10}-\delta$ is also not definitive. The investigation of the $\mathrm{CdIn}_{2} \mathrm{Se}_{4}$ $\mathrm{AgIn}_{11} \mathrm{Se}_{17}$ section recorded effects at $1020 \mathrm{~K}$ that, in our opinion, correspond to the invariant peritectic process $\mathrm{L}_{\mathrm{P} 6}+\mathrm{CdIn}_{6} \mathrm{Se}_{10} \Leftrightarrow \mathrm{Ag}_{0.4} \mathrm{Cd}_{0.4} \mathrm{In}_{6.3} \mathrm{Se}_{10}+\beta$.

\section{Conclusions}

X-ray phase, differential thermal, and microstructure analysis and microhardness measurements were used to construct for the first time six vertical sections, the 
isothermal section of the $\mathrm{Ag}_{2} \mathrm{Se}-\mathrm{CdSe}-\mathrm{In}_{2} \mathrm{Se}_{3}$ system at $820 \mathrm{~K}$ and the liquidus surface projection of the system onto the concentration triangle. The character of the monovariant processes and the temperatures of the invariant processes in the $\mathrm{Ag}_{2} \mathrm{Se}-\mathrm{CdSe}-\mathrm{In}_{2} \mathrm{Se}_{3}$ system were determined. The existence of solid solutions of the binary compounds $\mathrm{Ag}_{2} \mathrm{Se}, \mathrm{CdSe}$, and $\mathrm{In}_{2} \mathrm{Se}_{3}$, and of the ternary compounds $\mathrm{AgInSe}_{2}$, $\mathrm{AgIn}_{5} \mathrm{Se}_{8}$, and $\mathrm{CdIn}_{2} \mathrm{Se}_{4}$ was established. The largest solid solutions belong to $\mathrm{CdSe}$ ( $\gamma$-solid solution) and $\mathrm{CdIn}_{2} \mathrm{Se}_{4}$ ( $\varepsilon$-solid solution). The $\mu$-solid solution of the HT modification of $\mathrm{Ag}_{2} \mathrm{Se}$ has practically no extent into the concentration triangle. All the solid solution regions are stretched along the direction of the $\mathrm{CdSe}$ concentration change, therefore they can be regarded as solid solutions of the heterovalent substitution $\mathrm{Ag}+\mathrm{In}$ for $2 \mathrm{Cd}$ with the same number of atoms per unit cell. Near the $\mathrm{In}_{2} \mathrm{Se}_{3}$-rich part of the concentration triangle, the regions of the solid solutions of the ternary compounds diminish (Fig. 1). A quaternary phase was discovered in the $\mathrm{In}_{2} \mathrm{Se}_{3}$-rich part of the system. The compound forms in the peritectic reaction $\mathrm{L}+\mathrm{Cd} \operatorname{In}_{6} \mathrm{Se}_{10} \Leftrightarrow \mathrm{Ag}_{0.4} \mathrm{Cd}_{0.4} \mathrm{In}_{6.3} \mathrm{Se}_{10}(1055 \mathrm{~K})$. Its crystal structure has not yet been determined.

\section{References}

[1] V.O. Halka, I.D. Olekseyuk, O.V. Parasyuk, J. Alloys Compd. 302 (2000) 173.

[2] E.M. Kadykalo, O.F. Zmiy, I.D. Olekseyuk, Visn. Lviv Univ., Ser. Khim. 39 (2000) 53.

[3] O.F. Zmiy, I.A. Mishchenko, I.D. Olekseyuk, J. Alloys Compd. 367 (2004) 49.

[4] I.A. Ivashchenko, L.D. Gulay, O.F. Zmiy, I.D. Olekseyuk, J. Alloys Compd. 394 (2005) 186.

[5] L.I. Trishchuk, G.S. Oleinik, I.B. Misetskaya, Izv. Akad. Nauk SSSR, Neorg. Mater. 18 (1982) 1795.

[6] A.V. Vishnyakov, B.G. Iofis, Izv. Akad. Nauk SSSR, Neorg. Mater. 10 (1974) 1184.

[7] L.I. Trishchuk, G.S. Oleinik, I.B. Misetskaya, Thermochim. Acta 92 (1985) 611.

[8] O.V. Krykhovets, Ph.D. Thesis, Ivan Franko National University of Lviv, 2000.

[9] I.A. Mishchenko, O.F. Zmiy, I.D. Olekseyuk, Pol. J. Chem. 75 (2001) 1407.

[10] I.A. Ivashchenko, L.D. Gulay, O.F. Zmiy, I.D. Olekseyuk, J. Alloys Compd. 427 (2007) 101.

[11] I.A. Ivashchenko, O.F. Zmiy, I.D. Olekseyuk, Visn. Volyn. Univ., Ser. Khim. (in press). 